\title{
POWER AND INSECURITY: The POLITICS OF GLOBALISATION
}

Author:

Christi van der Westhuizen ${ }^{1}$

\section{Affiliation:}

${ }^{1}$ School of Politics,

University of KwaZulu-

Natal, South Africa

\section{Correspondence to:}

Allan A. Boesak

e-mail:

boesak@mweb.co.za

\section{Postal address:}

P O Box 1351, Sea Point 8060 South Africa

\section{Keywords:}

power imbalance; politics; globalisation; clothing industry; South Africa

\section{Dates:}

Received: 21 Aug. 2008 Accepted: 12 June 2009

Published: 06 Nov. 2009

How to cite this article: Van der Westhuizen, C. 2009, 'Power and insecurity: The politics of globalisation', HTS Teologiese Studies/ Theological Studies 65(1), 7 pages. Art. \#283. DOI: 10.4102/hts.v65i1.283

\section{This article is available} at:

http://www.hts.org.za

\section{Note:}

This article is a reworked version of a paper presented at a meeting of the Joint Globalization Task Team of the Reformed Churches of Germany and South Africa, held at Arnoldsheim, Frankfurt, Germany, 26-30 May 2008.

\section{(c) 2009. The Authors.} Licensee: OpenJournals Publishing. This work is licensed under the Creative Commons Attribution License.

\section{ABSTRACT}

Globalisation is presented by some as an inevitable force of history. However, it is very much the result of political and policy decisions made by powerful elites to advance their interests. Globalisation is not a benign, neutral process, but ideologically driven in the service of the rich and powerful. This ideology is neo-liberalism, which, in the name of 'competition' and 'efficiency', pursues a world in which the 'market' reigns over society. The impoverishment of Africa is a consequence of processes begun by political decisions in international organisations in which the odds are stacked against the South. Because of power imbalances, rules are made that disadvantage poor nations. Thus, international agreements have unequal outcomes. This article examines the effects of such decisions through the prism of the decimation of the clothing industry in South Africa. The article concludes with an exposition on insecurity as the leitmotif of the era.

'What had once been dedicated to the soul was now dedicated to the sale'. (John Kennedy Toole [1980] 2004:41)

\section{INTRODUCTION}

This article seeks to unpack the power dynamics underpinning the phenomenon called 'globalisation'. While globalisation is presented by some as unavoidable and inevitable, something akin to an irresistible force of history, this article argues that it is very much the result of political and policy decisions made by powerful elites to advance and defend their interests. Globalisation is not a benign and neutral process but - for the time being at least - ideologically driven in the service of the rich and powerful, globally. The reason for this is the ideology of neo-liberalism, which, in the name of 'competition' and 'efficiency', pursues a world in which 'the market' reigns supreme over society.

Approached from this angle, the continuing impoverishment of Africa becomes illuminated as a consequence of processes begun by particular political decisions. These decisions are put into effect by international organisations where the odds are stacked against Africa and the rest of the South. Because of the power imbalances in these institutions, rules are made that disadvantage poor and weak nations. Thus, international agreements are entered into with predictably unequal outcomes.

This article examines the effects of political decisions at both the international and the national levels through the prism of one particular example of such an inequitable outcome: the decimation of the clothing sector in South Africa. The article concludes with a brief exposition on insecurity as the leitmotif of the current era - by exploiting the relative weakness of countries, rules are forced upon nations, which remove whatever state protection exists for industry and citizens, replacing it with a condition of vulnerability. Regarding the position of citizens in this paradigm, neo-liberal proponents do not regard unemployment as a social problem but rather as a beneficial condition. Therefore, prosperity for the few is built on the back of insecurity for the many. This plays itself out at the global and the local level.

\section{NEO-LIBERAL GLOBALISATION FROM A POLITICAL VANTAGE POINT}

Let us begin with a simple exercise: sit back for a moment and think of the much-vaunted globetrotting 'global citizen' that we have all been entreated to become. What is the global citizen's sex? Where is the global citizen from? How is the global citizen earning a living? What is the global citizen wearing? What is the global citizen's skin colour? And finally, what would be a typical name for the global citizen? Would it be something like John Smith, a banker from London? or Peter Weismuller, a chartered accountant from Berlin? It would probably not be Rosalia Othieno, a rose grower in Nyeri in central Kenya, nor Maria da Silva, an unemployed resident of the barrios of Sao Paulo, nor Kim Meili, a seamstress in Keqiao town in eastern China.

This is an illustration of the effects of neo-liberal globalisation - who benefits and who does not. It shows the skewed interplay between identity, geography and the actualisation of the possibilities of globalisation. Those benefiting from the system travel, have money, are polyglot, and are 'linked together by affinities of culture and lifestyle' (Bourdieu 2003:43). This is because, despite the claims of globalisation being the great leveller, cultural capital remains unequally distributed and dependent on access to education and the familial transmission of economic capital (Bourdieu 2003:32). The result is that if you are white, male, and living in one of the metropolitan centres of the North, you are more likely to be reaping the benefits of globalisation.

This is true of even technology, one of the seemingly neutral drivers of neo-liberal globalisation. As Pierre Bourdieu (2003:32) has pointed out: 'The modal information technology user is a thirty-five year old, highly educated, English-speaking urban male with a high income.' This is in stark contrast to popular presentations of technology as the great equaliser that will pull every person and thus every country into the 'information economy' and level the playing field between North and South. The unequal outcome for individuals is also true for countries. The US Secretary of State, Condoleezza Rice, admitted this when she said the following about challenges facing US foreign policy: 
I would certainly focus on the impact of globalisation on economic stability in important countries. If I worry about anything, it is that there will be big winners and big losers in economic globalisation, that the impact could be very destabilising. Therefore, the international economic order is probably the most important challenge. ${ }^{1}$

Similar to the ideological presentation of technology as a neutral driver of change, globalisation is frequently misrepresented as an objective force of history (George 2004:14). This leads to decontextualised definitions, such as the following: globalisation is 'the closer integration of the countries of the world as a result of the lowering of transportation and communication costs, and the removal of artificial, man-made barriers' (Stiglitz 2003:xviii). This definition focuses on the technical aspects of globalisation to the detriment of the ideological aspects. The ravages sweeping poor countries are euphemistically reduced to being a result of the 'lowering of costs'.

Advocates of neo-liberalism tend to emphasise seemingly objective processes such as 'lowering of costs' and technological advancement as the factors driving globalisation while obfuscating underlying factors. As Bourdieu (2003:31) points out, with reference to technology: 'the social and economic changes in the world are the product of the socially and economically conditioned social uses made of technology' (emphasis added). The unequally shared advantages of technological advancement reveal the constraints built into the system, 'such as the logic of the transmission of cultural and academic capital, which is the precondition for the true mastery of the new tools, both technological and financial' (Bourdieu 2003:32). These factors, which are about access to resources and which are determined by power relations, are excluded from definitions of globalisation.

I would propose the following definition of globalisation, which combines the technical with the political, and emphasises its neo-liberal character: neo-liberal globalisation is the increasing interconnectedness between states, through the accelerated movement of goods, services, capital and, to a significantly lesser extent, labour across national borders - a process enabled by political decisions to deregulate capital and liberalise trade, and by related advances in technological capabilities. Therefore, these 'intensified processes of spatial interconnection' are associated with capitalist restructuring and are 'deeply infused with the exercise of power' (Hart 2000:12, 293).

Globalisation in itself is as old as humanity. One could say that it started when the first humans left Africa and spread to other continents. This necessitates an identification of the current processes of globalisation as neo-liberal, in that it is advancing a particular type of capitalism akin to the laissez-faire variety embraced by European states in the mid-19th century and that continued to be pursued by Britain and others until the Wall Street crash in 1929 (Hobsbawm 1987:40-43). That version of capitalism also had as its centrepiece the deregulation and liberalisation of trade and capital flows.

Today's neo-liberal capitalism utilises the lexicon of liberty, liberalism and deregulation to grant economic determinisms a fatal stranglehold by liberating them from all controls, and to obtain the submission of citizens and governments to the economic and social forces thus "liberated"'(Bourdieu 2003:38).

Thatcher is notorious for declaring: 'there is no such thing as society'. Economists of the Chicago school sketched a picture of human beings as selfish utility maximisers, spurred on by materialism and consumerism - Homo economicus (Hertz 2001:27). The social Darwinism of 19th century colonialism makes its reappearance, 'as the rationality postulated by economic theory (becomes) the product of the natural selection of the most

1.Condoleezza Rice, July/August 2008, 'Rethinking the national interest: American realism for a new world, in Foreign Affairs, published by the Council American realism for a new world, in Foreign Affairs, published by the Council
on Foreign Relations, viewed on 25 September 2009, from http://www.cfr.org/ on Foreign Relation
publication/16516/. capable' (Bourdieu 2003:34). This has developed into a 'racism of intelligence' in which the causes of poverty are seen to be intellectual incapability rather than older classist 'explanations' such as being spendthrift or lazy (Bourdieu 2003:33).

Neo-liberal globalisation contains a paradox in that it is a 'policy of depoliticisation'. It seeks to elevate economic power above conventional political power - which holds dire consequences for democracy. Neo-liberalism has colonised the political sphere and is dominating to a greater or lesser extent the political discourse from Lilongwe to Brussels, Washington to Santiago.

J.K. Galbraith (2004) has compiled a list to cut through neoliberal mythology's 'economics of innocent fraud'. The first is the renaming of capitalism to 'the market' to 'disguise the deeper corporate reality, (i.e.) producer power extending to have influence over, even control of, consumer demand'. In this way, the reality of economic power is obfuscated (Galbraith 2004:10). The second is measuring social progress by the volume of production of material goods and objects only, as is done through the measurement of gross domestic product (Galbraith 2004:15-16). The third is the paradoxical status of work: while those who least need compensation, while being the ones who most enjoy their work (which is roundly regarded as prestigious), are paid the most, those who are most dependent on work do the most repetitive and tedious work for the lowest wages. Simultaneously, idleness and leisure are commended for the rich and condemned for the poor (Galbraith 2004:18, 20). The fourth is the denial of the existence of bureaucracy in the corporation. Individualistic pursuit and acumen are emphasised to explain success in the private sector while the role of bureaucracy is denied. 'Inefficient' bureaucracy is associated with the public sector. Furthermore, the impression is given that owners (stockholders, investors) are the authority in corporations at annual meetings, but this is merely ceremonial as managers control all aspects of the business, including the salaries they pay themselves (Galbraith 2004:24-26). The corporate system is based on an unrestrained power of self-enrichment in a milieu where the pursuit of money is uncritically accepted. The fifth is the divide between the public and private sector. This is shown to be increasingly true as the private sector takes over more public sector functions, particularly in determining defence policy in the USA (Galbraith 2004:33-34).

Another paradox is that the neo-liberal project is made possible by the very power that it is seemingly seeking to subjugate: the state. In accordance with the neo-liberal dictum 'roll back the state', governments are voluntarily divesting themselves of the ability to control the newly unleashed forces. States themselves enact decisions that erode their control over certain social and economic forces (Bourdieu 2003:49). Robert W. Cox (1987:253254) describes this process as the internationalisation of the state': the adjustment of national policies and practices to the exigencies of the world economy of international production. Neo-liberalism furthermore rejects the idea that the state exists to ameliorate market failures, an idea that held sway after the Second World War when Keynesian capitalism was the dominant paradigm in capitalist countries. The North, at that point, consciously decided to institute a system of capital controls and fixed currencies, administered by the Bretton Woods Institutions, to prevent lenders, investors, corporations and banks from running domestic economies. This led to the 'golden age of capitalism' when the highest level of economic growth was clocked (Chomsky 2005). With the ascent to power of Reagan in the USA and Thatcher in the UK in the 1980s, the push started to pare the state's role down to that of 'night watchman', i.e., to merely enforce contracts and ensure that market forces were not distorted (Hertz 2001:24-25). The state's functions were no longer to ensure full employment, to redistribute wealth, or to provide welfare protection against the socially destructive aspects of market operation, as during the Keynesian era. Therefore, as Chomsky says, the state's reduced role is by its own design. 
While the state's role has been diminished, this condition should not be overstated. Governments insist that they are powerless to act against the 'forces of globalisation' (George 2004:104). It is more accurate to speak of a changed role for the state. Thus Boris Kagarlitsky (in Pilger 2002:5) declared on occasion: 'Globalisation does not mean the impotence of the state but the rejection by the state of its social functions in favour of repressive ones; (it means) irresponsibility on the part of governments; and the ending of democratic freedoms'. We can say that the state is returning to its role in the laissez-faire period.

As David Harvey (2003:92) says: when it comes to global hegemony, the state 'has long been and continues to be the fundamental agent in the dynamics of global capitalism'. The nation state has for a long time maintained order on behalf of capital and that has not changed (Meiksins Wood 2005:137-142). It is useful to remember that the state remains the only entity that can exercise force legitimately. No other institution has been able to play the roles of the state as administrative and coercive guarantor of social order, property relations, stability or contractual predictability, or any other conditions that require capital on a daily basis. Presently, while the state has withdrawn from its social ameliorative functions, it is still dispensing social services to ensure social stability in the capitalist centre of the world order. Looking at the North, what David Harvey calls 'the new imperialism' depends on a system of multiple states, with global capital requiring several states to perform the administrative and coercive functions necessary for maintaining property relations and other legal conditions for capital's reproduction. Imperial hegemony relies more than ever on an orderly system of many local states, and global economic hegemony is about keeping control of these states (Meiksins Wood 2005:137-142).

Proponents of neo-liberal globalisation, including the World Bank, are now also promoting the idea of a stronger state. As John Ralston Saul (2005:250-251) warns, advocates such as Fukuyama and Milton Friedman both are insisting on the re-establishment of the authority aspect of neo-liberal globalisation, i.e., the state's ability to enforce the rule of law and to preserve 'world order' through the deployment of power. The danger here is that they do not refer to the state's other function, i.e., to act in the public good.

The reshaping of the state is effected through external pressures and 're-alignments of international power relations' among domestic social groups, says Cox (1987:253-267). The political driving forces behind globalisation are therefore at least partially grounded at the national level. State level contestations therefore still remain significant in the permutations that globalisation adopts. George (2004:102-103) points out that it remains still more effective for citizens to apply pressure on, for example, the member states of the European Commission (EC) than it is for citizens to attempt to change the course of the EC. This is because the EC is acting on instructions from its member states. However, the European Uniuon (EU)'s supranational structure has been repeatedly criticised for its 'democratic deficit' in which accountability is low. It is more conducive to participation in decision-making processes by organised stakeholders than by the citizenry at large (Magnette 2003:144-145;149).

Therefore, organised business lobbies can have a disproportionate impact. It has been found that, on average, political outcomes are biased in favour of business interests, of which the increasingly unequal distribution of income in liberal democracies is the epitome (Bernhagen \& Brauninger 2005:45). As has been mentioned, the liberal state has historically been structurally interlinked with capital and has used, and in some cases even ceded, its monopoly on violence to advance the interests of capital (viz., colonial wars or violent colonial settlement by corporate interests). The entwinement of capital and state can also be seen in the state's developing most aspects of the 'new economy': for example, electronics, telecommunications, the Internet, lasers and computers have been developed in the public sector and then handed over to the private sector to profit from (Chomsky 2005). From colonial times onwards the state has paved the way in terms of making the world conducive to their corporations' expansion. Chomsky (2005) quotes James Madison as saying, two centuries ago, that business acts as the 'tools and tyrants' of governments, making them virtually indistinguishable. Corporations have turned into private tyrannies, as they are legally required to make a profit without paying heed to the social effects of their behaviour. To improve profit, they compulsively attempt to externalise the costs of their activities, for example, by destruction of the ecology or the reproduction of workers through women's unpaid labour. While they have the legal rights of persons they are unaccountable to the public. Chomsky calls them totalitarian.

At the level of agency of actors, policy makers remain mindful that redistribution negatively affects capital's profit-making prospects, leading to reduced investment and concomitant slower growth, which has a negative influence on employment and leads to decreased tax revenues (Chomsky 2005). However, this suggests an objective process, which does not reflect the full reality. Elite theory proposes that not only are liberal democracies subordinated to corporate interests but that the political interests promoted by business have origins outside of corporations, i.e., 'they belong to social groups with an existence that is independent of the corporate community' (Bond 2007:60). Indeed, political action by corporates is illegitimate as it is based on their social groups' political needs rather than those of the corporates' stakeholders (Bond 2007:60). Bond (2007:8182 ) found that directors of corporations' social networks of relationships, based on schools and clubs attended, influenced them in their decisions about donations to the Conservative Party in Britain. They continued funding the party despite its decline at that point (the mid-1990s). A more rational step would have been to fund the incoming Labour Party. Indeed, Bond found that social groups had hijacked the authority of corporations to promote their own narrow, parochial, sectional interests, as the corporations exhibited political behaviour that was unrelated to corporate interests (Bond 2007:82). This issue of agency - actors that determine the behaviour of corporations - is important. It explains the obvious promotion of self-interest as is seen in the huge growth in CEOs' remuneration, frequently despite poor company results or even fraud, for example, Enron (Stiglitz 2003). The deregulation of companies has been exploited to the detriment of their employees and broader society, leading to several corporate scandals - from the US to Italy, and elsewhere.

Apart from states, these policies of unleashing economic forces are incubated in the World Trade Organization, the European Union and the networks of multinational companies (Bourdieu 2003:38).

The following section will explore the effects of the policy of 'one-size-fits-all' trade liberalisation on women working in South Africa. It shows how political decisions at the national level are tailor made to fit the dominant international ideological paradigm with scant regard to national or democratic imperatives, such as the socio-economic rights enshrined in South Africa's constitution.

\section{A CASE STUDY: THE SOUTH AFRICAN CLOTHING SECTOR ${ }^{2}$}

Apart from the Bretton Woods Institutions, the World Trade Organization (WTO) is the other principal institution influencing international economic relations. It is also the most important institution determining the evolution of multilateral trade agreements. The World Trade Organization emerged from the

2.An earlier version of this section was published as Van der Westhuizen, $C, 2007$. 'Trade and poverty: A case study of the South African clothing industry', in Journal for Studies in Economics and Econometrics 31(2) Stellenbosch: Bureau for Economic Research/Graduate School of Business. 
General Agreement on Tariffs and Trade (GATT). The four key principles of the GATT are: protectionist measures should take the form of tariffs and not import quotas or non-tariff barriers; reciprocity, meaning if one contracting party lowers its tariffs against another's exports then the other party should do likewise non-discrimination, meaning no state will grant preferential treatment to another state or group of states, thereby extending to each other the most favourable terms (most favoured nation [MFN] treatment); and a commitment to periodic multilateral negotiations on tariff reductions (Coote and LeQuesne 1996:105106). The WTO was created through the Uruguay Round of the GATT (1986-1995), under which the scope of multilateral trade regulation was expanded beyond trade at borders to the 'globalisation of policy making' (Khor 2000:11) by easing the flow of services and investments across borders through changing states' domestic policies regarding foreign investment and economic regulations (Coote and LeQuesne 1996:111).

States that have signed on to the WTO face losing 'mostfavoured-nation' status if they do not comply with WTO disciplines regarding economic policies of trade, investment, sectoral policies in services, and agriculture and technology. Current and future national policies will have to comply with what is permissible within WTO agreements (Khor 2000:12-13).

In 1986, at Punta del Este in Uruguay, it was decided that agriculture, subsidies and textiles would be on the 'list of priorities' for negotiations, including bringing agriculture into the GATT ambit, elaborating on the use of subsidies and attending to the protectionist regime that applies to textiles (see LoongHoe Tan 1988:159). John Groome ([1995] 1999:32-36) argues that the outcome of the Punta del Este Declaration 's Uruguay Round was a combination of liberalisation and protectionism aimed at allowing northern corporations access to southern markets, while protecting technological monopolies. This was done through the Agreement on Trade-Related Intellectual Property Rights (TRIPS), Agreement on Trade-Related Investment Measures (TRIMS) and the General Agreement on Trade in Services (GATS). The end result of the Uruguay Round is much reduced power for governments to restrict corporate 'freedom'. As discussed above, national sovereignty has been undermined, as well as labour and environmental standards and gender equity in developing countries (Karns and Mingst 2004:385). Predictably, the developed states will accrue $70 \%$ of the additional income generated by the Uruguay Round while only comprising $20 \%$ of WTO members (Khor 2000:21, 23).

Regarding clothing and textiles, these industries were finally brought into the GATT/WTO ambit between 1994 and 2005 with the WTO Agreement on Textiles and Clothing (ATC). In a paradoxical outcome, developing countries have lost their small foothold in clothing markets in the developed world to China, in particular. The ATC brought to an end the MultiFibre Agreement (MFA), enacted in 1974 and renewed several times since. While the MFA was widely acknowledged as trade distorting, this distortion had paradoxical development effects. The agreement protected industrialised countries' markets by limiting clothing imports from developing countries through quotas. However, the quotas produced unexpected positive spin-offs by enabling industrial growth in some least developed countries (LDCs).

The reason for this is that as clothing exporters reached the ceilings of their allotted MFA quotas in their countries, they started clothing manufacturing in other countries that still had open quotas under the MFA. In the process they boosted development and employment in several LDCs. African countries that faced losses with the end of the MFA include Uganda, Namibia, Zambia, Madagascar, Lesotho, Mauritius and South Africa. Hopes that the United States' Africa Growth and Opportunity Act (AGOA) would ameliorate the effects of the end of the MFA were dashed.
One of the stated aims of policies of economic openness and trade liberalisation is poverty reduction through growth (Culpeper 2005:4). Despite the aims of such policies, trade liberalisation may detrimentally impact on income distribution through 'exposing previously protected domestic industries to greater foreign competition, causing income and employment losses' (Culpeper 2005:11). The case of the clothing industry in South Africa provides an illustration of such an outcome, as the liberalisation of trade in South Africa precipitated the decline of the clothing industry and resultant employment loss. While other economic factors also contributed to its deterioration, the government has acknowledged that global exposure has placed the industry in a 'difficult period', necessitating restructuring. Restructuring has involved the contraction of the formal sector of the industry, the shedding of jobs and the informalisation of the industry (Altman 1993; ESSET/EPRI 2003; USITC 2004; Van der Westhuizen 2005).

From the 1980s onwards the South African clothing sector has increasingly been exposed to international competition, a process that was significantly accelerated when South Africa acceded to the WTOs ATC in 1994. Taking a step back, this was made possible by the shift to neo-liberalism in South Africa while the National Party (NP) was still in power. This shift was confirmed in post-apartheid South Africa with the ANC-led government's adoption of the Growth, Employment and Redistribution (GEAR) programme in 1996. Disturbingly, GEAR showed remarkable similarities with the NP's Normative Economic Model, released in March 1993. These include: the emphasis on combating inflation and reducing state expenditure, improved international competitiveness and industrial reorientation towards export markets' tax reductions, boosting small business, relaxing exchange controls and containing wage increases (Van der Westhuizen 2007).

From the South African government's vantage point, economic and political imperatives necessitated economic policy that would promote international openness, partly to deal with profitability and productivity problems in the manufacturing sector, as reflected in trade and balance of payment problems. Clothing and textiles tariffs were dismantled at a faster rate and over a shorter period than required by the ATC. This translated into the industry being ill prepared for the resultant swift rise in clothing imports, with the bulk emanating from China. As indicated above, the South African clothing industry has also been unable to compete with China in the primary clothing markets of the EU and US after the MFA ceased to exist on 1 January 2005.

The predominantly female workers have had fewer options to adjust to the changes, with the consequences of restructuring being acute for these workers. The primary welfare impact has been similar to other cases where developing states embarked on rapid or incorrectly sequenced reforms, such as liberalisation, where such reforms caused social disruption through 'considerable and long-lasting' unemployment (Stiglitz 2002 in Culpeper 2005:11). South African studies on employment losses in the clothing industry have shown there to be two reasons for social dislocation (ESSET/EPRI 2003; Van der Westhuizen 2005; Van der Westhuizen \& Deedat 2003). Firstly, prior to employment loss these workers were low-wage earners who increasingly found themselves to be the sole breadwinners as jobs in other sectors were lost, which has meant that after these workers' employment loss such households have been pushed into poverty. Secondly, these workers cannot find alternative employment due to limited economic diversification and the low rate of job creation and, hence, labour absorption in South Africa. The latter point is strengthened by experiences elsewhere:

Between 70 and 80 percent of the workers in the clothing sector are women in most poor countries, and many - perhaps most of them - would not have had an income in the formal sector in the absence of the clothing industry. If we assume that these workers 
have a higher income and higher productivity in the clothing sector than in their best alternative economic activity, the income gains in poor, clothing-exporting countries are higher than (economic model estimates)

(Nordas 2004:30-31)

Many clothing workers in developing countries would not have an income in the formal sector were it not for the clothing industry (Nordas 2004:30-31). Some trade theorists posit that workers retrenched from uncompetitive industries will experience a short period of frictional unemployment before undergoing training and accessing new employment opportunities. However, developing countries frequently suffer low investment levels, which results in sub-optimal job creation, as has been seen in South Africa - with its capital formation level of only $16 \%$ of GDP. Therefore, restructuring has been associated with growing unemployment, and re-employment levels in the clothing industry have been low (ESSET/EPRI 2003:10). The labour intensive nature of the clothing industry provides it with a social function to absorb relatively low-skilled labour, which is otherwise currently not being absorbed in the South African economy. Page (2004:2) notes that ameliorating the negative consequences of trade policy through social policy and administrative targeting is complex, which accords more importance to the analysis of first round effects of changes in the trade regime. Whether such considerations have played a role in the policy decision to liberalise clothing trade is unclear.

When identifying those more exposed to trade-related shocks, vulnerability by livelihood group, socio-cultural identity and geographic location should be investigated (Page 2004:6). Clothing workers fall into the livelihood groups ' urban industrial workers' and 'rural industrial workers', categories characterised by low entry barriers (e.g. skills), low wages and high levels of drudgery (Page 2004:6). Some 86\% of the workers in the South African clothing industry are women, which fits the worldwide trend. Women are regarded as particularly 'suitable' workers for the clothing industry because of their perceived capacity for long periods of physical immobility, patience, dexterity and for their 'docility' (Benería and Roldán 1987:44-49, in Van der Westhuizen 2003:21).

Labour flexibility is associated with the international increase of female labour, and is a gender, race and class construct, as black and working class women predominate in unregulated, lowwage, low-skill, low-status jobs (Van der Westhuizen 2005:338). In South Africa, clothing workers are geographically and racially differentiated, with black women predominating in the industry in the rural areas of KwaZulu-Natal and coloured women predominating in the industry in the urban areas of the Western Cape. Therefore, poor women of colour absorb the social costs of liberalisation, as shown in the case of the clothing industry in South Africa over the past 15 years.

Livelihood strategies for retrenched clothing workers are limited by the dearth of economic opportunities in communities that are already under stress and under-resourced. Firstly, prior to employment loss these workers were low-wage earners who increasingly found themselves to be the sole breadwinners as jobs in other sectors were lost, which has meant that after these workers' employment loss such households have been pushed into poverty. Secondly, these workers cannot find alternative employment due to limited economic diversification and the low rate of job creation and, hence, labour absorption in South Africa. The limited employment opportunities in Mitchell's Plain, for example, cause clothing workers to arrange employment for family members at the clothing factories where they are employed, with the result that a factory closure can cause a household to lose all its breadwinners in one foul swoop (Van der Westhuizen and Deedat 2003).

Moreover, women's employment loss can be devastating in poor communities as the effects are felt beyond the individual worker who loses her job. Studies in developing countries have shown women to be essential for the maintenance of livelihoods in poor families given that they are more likely to spend their income on the needs of other family members, and children in particular (Momsen 2001:1-2; Page 2004:8). In South Africa, the lack of economic opportunities for the poor majority means that livelihood options are diminished to desperate actions such as begging for food from neighbours, creating a snowball affect in which whole communities have to absorb the impact of job losses in the clothing sector (Van der Westhuizen and Deedat 2003). Studies have shown differential effects on family members according to gender, with women and children bearing the brunt of employment loss. Unequal power relations in the home ensure that the employed male partner's standard of living is frequently not affected by the female partner's job loss, as the consequences of the woman worker's job loss are offloaded onto her and her children (ESSET/EPRI 2003:14, 36).

Respondents in the ESSET/EPRI study indicated that clothing workers in metropolitan areas support at least four dependants, while those in non-metropolitan areas support at least six dependants. In Newcastle in the KwaZulu-Natal hinterland, unemployment stands at $60 \%$, which explains the higher number of dependants per worker. Other studies have found higher numbers of dependants of clothing workers in urban areas. The rate of absenteeism in the clothing industry, which is notoriously high $(7 \%)$, is ascribed to the social problems with which these women have to cope, including being the sole breadwinner, alcoholism, drug abuse, domestic violence, gang violence and women's continuing role as the caregiver within the household.

These pressures increase after retrenchment. A study published in 2003 found that retrenchment led to a 'significant and sustained decline in household income, severely constraining the ability of households to maintain expenditure on healthcare, education and food' (ESSET/EPRI 2003:13). In all, 68\% of households reported the reduction of income spent on food as a coping mechanism since job loss, as budgets left little room for reallocation of other expenses. In $34 \%$ of households someone went without food because of lack of money. In $25 \%$ of households a child went without food because of lack of money. Some $76 \%$ of households reported being affected by the loss of health insurance. Loss of health insurance has a destructive multiplier effect, as the workers' family members are frequently reliant on the workers' sick fund for access to health care. Some $60 \%$ of interviewees were supported by another employed person in the household, and 27\% were supported by people outside the household (ESSET/EPRI 2003:37, 39, 40). While urban and rural workers frequently access the available social security support mechanism - the child support grant - social security as provided by government is inadequate to buffer the shock, leading to the respondents in the study reporting reduced access to healthcare and a decrease in food consumption. Poor nutrition, health and education undermine families' attempts to prevent a further slide into poverty (ESSET/EPRI 2003:13).

Another study (Van der Westhuizen and Deedat 2003) revealed that more than half of the respondents were the sole breadwinners in their homes before retrenchment. Respondents reported children being denied access to education because the parent was unable to pay school fees. Confirming the findings of the ESSET/EPRI study, unemployed clothing workers were forced to make trade-offs between different needs, having to choose between purchasing food, paying for transport to look for a job, or buying pay-as-you-go electricity. Respondents frequently found themselves in a spiral of debt, as they borrowed money to cover basic needs. Another coping strategy is the pooling of resources, as retrenched workers move in with employed family members, or send their children to live with employed family members. These strategies highlight the pressure that families are placed under, and the resultant social fragmentation (Van der Westhuizen \& Deedat 2003:18, 21, 25). 
Finally, opportunities for re-employment are frequently limited to small home-based clothing sweat shops called 'cut, make and trims' (CMTs), with the concomitant problems of non-payment, underpayment, inconsistent payment, lack of social insurance, long hours and unhealthy working conditions. Retrenched women clothing workers cannot find work in the regulated, formal economy, and are therefore forced to work in the unprotected conditions of the CMTs. The primary characteristic of the CMT is its invisibility to regulators, as these operations are situated in households or on residential premises and are of a short-lived, up-and-go nature. Therefore, non-compliance with National Bargaining Council (NBC) agreements and nonregistration with the NBC are rife. Some 877 CMTs employing 24000 workers were to have writs of execution issued against them for failing to comply with NBC agreements, including registration and conditions of employment. Apart from illegal arbitrary variations in wages (from as little as R50 per week to R450 per week in both the non-metropolitan and metropolitan areas in 2005), CMT employers under-register the number of workers in their employ to reduce levy costs. Some 700 small operators may be prosecuted for not paying the minimum wage as agreed in the daily used (NBC) clothing. ${ }^{3}$

In KwaZulu-Natal alone, the CMT Employers' Organisation has 162 members who employ a total of 8500 workers, but it estimates the number of CMTs in the province to be at least 500, representing another 17000 workers. Therefore, at least $438 \mathrm{CMTs}$ in KwaZulu-Natal are not registered with the NBC, the reason being avoidance of the levies associated with registration. These levies include provident fund and health care levies. A registered business also has to pay into South Africa's Unemployment Fund (UIF) for each worker, the Sector Training Authority (SETA) levy, and allow workers paid leave, paid public holidays, and 10 days paid sick leave annually. According to CMT employers, they cannot afford these costs because payment for production is too low in the context of price suppression.

In summary, the invisibility of CMT workers ensures they have little bargaining power, causing these workers to be subjected to unhealthy working conditions, including long hours, inconsistent or no payment for work rendered and no social insurance. CMT workers absorb the costs of the seasonality of clothing production, earning less money or even no money in cases where workers fall prey to fly-by-night operations.

In survivalist operations the conditions are the worst, as unemployed family members render unpaid work to 'help out' and children in the household are drawn in to supply labour. Working conditions are often unhealthy and unsafe, with inadequate ventilation and unsafe electricity supply and machines. Therefore, the social costs of restructuring are not only absorbed by the women who used to work in the industry but who, because of the adjustments, cannot find employment, but also by their families.

The question that arises in the context of a study on trade and poverty is whether export production, a solution proffered by neo-liberals, could boost employment creation. The South African clothing industry is comparatively unusual, as it supplies both the domestic and foreign markets. Market share has been lost to imports, as the latter increased from $7 \%$ of domestic consumption in 1995 to $20 \%$ in $2002{ }^{4}$

Reorientation towards export production has been strongly espoused, and backed up by government support, but only companies able to attain economies of scale or to access niche markets have been successful. Exports in rand value doubled between 1995 and 2000, and increased by another $50 \%$ by 2003,

3.cf. Van der Westhuizen, C., 2007, 'Trade and poverty: A case study of the South African clothing industry', Journal for Studies in Economics and Econometrics African

4.Quantech, 2004, 'South African Standarded Industry Database Sources and Descriptions' viewed 1 December 2005, from http://www.hps.org.za/data/. only to suffer a setback with the appreciation of the currency. In 2004, export fell back to below 2002 levels. A number of clothing manufacturers had been exporting apparel to the US and EU markets for a substantial period of time - some having started during the apartheid years. The numbers have been disappointing, however, with about 150 exporters out of a total of 2000 clothing manufacturers registered with SETA.

The potential for export growth was arrested with the appreciation of the rand, resonating with Culpeper's (2005:11) assertion that 'greater openness may be associated with greater volatility and economic shocks, for example, through capital surges or shifts in the terms of trade'. Vulnerability to such volatility is especially true for developing states pursuing policies of economic openness, as the financial crises of the past decade in Latin America and South East Asia have illustrated. In South Africa, the currency's movements have greatly affected the ability of manufacturers to export competitively, which has translated into job losses. It has also meant that the potential for export manufacturing to create jobs has not been realised, meaning that workers that have lost their jobs have not been re-absorbed. This bears out Culpeper's statement (2005:11) that 'volatility ... tends to affect the vulnerable and the poor the most'.

Established companies, which are large job providers, have experienced setbacks because of the rand's appreciation. The largest clothing manufacturer in Southern Africa, Seardel, reported that its clothing exports dropped by $53.5 \%$ from 2003 to 2004 as a result of the stronger rand, accounting for $9.2 \%$ of total revenue in 2004 as opposed to $19.9 \%$ in 2003 (Seardel Interim Report, 2004). Its woes continued as its headline earnings per share decreased by $30 \%$ between 2004 and 2005 (Business Report, 23/08/2005). Examples of mass production manufacturers who closed down because of the turn in the rand include

- several large KwaZulu-Natal CMTs (with around 300 workers each), which exported jeans to the US

- a foreign investor withdrew in the wake of the rand's appreciation after setting up a large factory in Atlantis near Cape Town to produce jeans for export.

Only a 'small percentage' remains of those exporters who in 2001-2003 had been exporting on the back of the then weaker rand.

Moreover, the preferential access to the US market afforded by the United States' Africa Growth and Opportunity Act (AGOA) did not compensate for the currency's strength. South African exports have fallen substantially since 2003, while exports from other AGOA signatories have been rising continuously. While the year-to-date figures for 2004 and 2005 are lower for AGOA exports overall - possibly reflecting the end of the MFA - South Africa's figure for 2005 is almost 50\% less than that for 2004. While the currency is not the only factor in the decline of exports under AGOA, it shows that a setback such as a stronger currency in conjunction with another factor, such as poor textile supply, can cancel the viability of exporting. The AGOA tripletransformation rule - that not only fabric but also yarn should be sourced from either the US or signatory states - has prejudiced South Africa and Mauritius, which do not enjoy lesser developed status under AGOA, such as Kenya.

As has been seen, export growth has not been able to alleviate the employment crisis as its fortunes turned with the appreciation of the rand. Other reasons for sluggish export growth have also been discussed. Export growth can still contribute to job creation and therefore poverty alleviation but the problems need to be addressed first.

\section{CONCLUSION}

The case study of the clothing industry reveals the functionality of insecurity in the neo-liberal system. The decentralisation of 
production is spurred on by the search for lower labour costs. Labour costs are lower in some countries because of the lack of democratic and human rights and therefore workers' rights in those countries. Therefore, decentralisation of production is enabled by the existence of vulnerable workers, especially in the South. In this process, the position of workers in the North is fundamentally weakened because they are brought into direct competition with workers in undemocratic states or states with limited or no human rights regimes. In this way, the carefully constructed social security of people built after the Second World War in developed countries is also being demolished. By increasing the pool of vulnerable workers inside countries and globally, the positions of employed people are also weakened.

The attack against working people is furthermore accomplished in very real ways such as the proliferation of types of employment, such as contract, casual, temporary work and the outsourcing to informal operations. Indeed, we have seen massive informalisation of work, with factories closing and unregulated operations springing up outside of the reach of governing authorities and trade unions. This makes workers even more vulnerable and unable to bargain a living wage and a decent work. Therefore, the system preys on vulnerability. Profit is generated from insecurity. Therefore, the overturning of the post Second World War balance of power between government, capital and labour is being further entrenched in favour of capital.

Lastly, Cox (1987:253-254) concludes that there is 'nothing inevitable' about the continuation of the internationalisation of the state and of production, i.e., globalisation. He points out that the processes of globalisation can provoke countertendencies among excluded groups which may reverse the process, especially if this resistance happens simultaneously in a number of countries. The ever increasing global inequality and inequality within nations is a recipe for social destabilisation. John Ralston Saul's disconcerting reminder is that the last time the claim was made that neither military nor political power could stop the market was in 1911 - just before nations descended into a hellish war.

\section{REFERENCES}

Altman, M., 1993, Tinker, tailor, tailor's son: Developing the SA clothing industry. Report submitted to the Industry Strategy Project of the Congress of South African Trade Unions.

Bernhagen, P. \& Bräuninger, T., 2005, 'Structural power and public policy: A signalling model of business lobbying in democratic capitalism', Political Studies 53, 43-64.

Bond, M., 2007, 'Elite social relations and corporate political donations in Britain', Political Studies 55, 59-85.

Bourdieu, P., 2003, Firing back: Against the tyranny of the market 2, Verso, London.

Chomsky, N., 2005, State and corporation, viewed 09 May 2008, from www.z-net.org.

Coote, B. \& LeQuesne, C., 1996, The trade trap: Poverty and the global commodity markets, Oxfam, Oxford.

Cox, R.W., 1987, Production, power and world order: Social forces in the making of history, Columbia University Press, New York.

Culpeper, R., 2005, Approaches to globalisation and inequality within the international system. Overarching concerns programme, no 6. UN Research Institute for Social Development, Geneva.

Ecumenical service for socio-economic transformation (ESSET)/(Economic policy research institute (EPRI) 2003. The impact of trade liberalisation on workers in the South African textile industry. Research report, Marshalltown.

Galbraith, J.K., 2004, The economics of innocent fraud, Penguin, London.

George, S. 2004. Another world is possible if ..., Verso, London.

Groom, J., [1995] 1999, Reshaping the world trading system: A history of the Uruquay Round, 2nd edn., World Trade Organization, Geneva.
Hart, G.P., 2000, Destabilising globalisation, University of KwaZulu-Natal Press, Scottsville.

Harvey, D., 2003, The new imperialism, Oxford University Press, Oxford.

Hertz, N., 2001, The silent takeover: Global capitalism and the death of democracy, Arrow Books, London.

Hobsbawm, E., 1987, The age of empire: 1875-1914, Abacus, London.

Karns, M. P. \& Mingst, K.A., 2004, International organizations: The politics and processes of global governance, Lynne Rienner Publishers, London.

Kohr, M., 2000, Globalization and the South: Some critical issues, United Nations Conference on Trade and Development, Geneva.

Loong-Hoe Tan, M.A., 1988, ASEAN trade policy options: The Uruguay round, Asean Economic Research Unit, Singapore.

Magnette, P., 2003, 'European governance and civic participation: Beyond elitist citizenship?', Political Studies 51, 144-160.

Meiksins Wood, E., 2005, Empire of capital, Verso, London.

Momsen, J.H., 2001, Women and development in the third world, Routledge, London.

Nordas, H.K., 2004, The global textile and clothing industry post the Agreement on Textiles and Clothing. Discussion 5. World Trade Organization, Geneva.

Pilger, J., 2002, The new rulers of the world, Verso, London.

Page, S., 2004, Trade and poverty linkages study, Department for International Development, London.

Saul, J.R., 2005, The collapse of globalism, Atlantic Books, London.

Stiglitz, J., 2003, The roaring nineties: Why we're paying the price for the greediest decade in history, Penguin, London.

Tool, J.K., [1980] 2004, A confederacy of dunces, Louisiana State University Press, Baton Rouge.

US International Trade Commission, 2004, Textiles and apparel: Assessment of the competitiveness of certain foreign suppliers to the US market, viewed n.d., from http://63.173.254.11/ pub3671/main.html.

Van der Westhuizen, C., 2003, Women's experience of neoliberal globalisation during the democratic transition in South Africa: Home-based work in Cape Town. MPhil treatise, Nelson Mandela Metropolitan University.

Van der Westhuizen, C., 2005, Women and work restructuring in the clothing industry, in E. Webster \& K. von Holdt (eds.), Beyond the apartheid workplace: Studies in transition, n.p., University of KwaZulu-Natal Press, Scottsville.

Van der Westhuizen, C., 2007, White power $\mathcal{E}$ the rise and fall of the National Party, Zebra Press, Cape Town.

Van der Westhuizen, C. \& Deedat, H., 2003, The socio-economic impact of trade liberalisation and employment loss on women in the South African clothing industry: A Cape Town case study, Economic justice network of the fellowship of Christian councils in South Africa (FOCCISA), Cape Town. Unpublished report. 